\title{
IDENTIFICATION AND CHARACTERIZATION OF THE ENDOPHYTIC PLANT GROWTH PROMPTER BACILLUS CEREUS STRAIN MQ23 ISOLATED FROM SOPHORA ALOPECUROIDES ROOT NODULES
}

\author{
Longfei Zhao ${ }^{1,2}$; Yajun $\mathrm{Xu}^{2}$; Ran Sun ${ }^{1}$; Zhenshan Deng'; Wenquan Yang ${ }^{1}$; Gehong Wei ${ }^{1 *}$
}

${ }^{1}$ College of Life Sciences, Shaanxi Key Laboratory of Molecular Biology for Agriculture, Northwest A \& F University, Yangling, Shaanxi, 712100, China; ${ }^{2}$ College of Life Sciences, Shangqiu Normal University, Shangqiu, Henan, 476000, China.

Submitted: July 01, 2010; Returned to authors for corrections: October 05, 2010; Approved: January 13, 2011.

\begin{abstract}
Endophytes MQ23 and MQ23R isolated from Sophora alopecuroides root nodules were characterized by observing their ability to promote plant growth and employing molecular analysis techniques. Results showed that MQ23 and MQ23R are potential $\mathrm{N}_{2}$-fixing endophytes and belong to the same species as Bacillus cereus. MQ23 was shown to be able to produce siderophores, IAA, and demonstrate certain antifungal activity to plant pathogenic fungi. Co-inoculation with MQ23+MQ23II showed a more significant effect than inoculation alone in vitro for most of positive actions suggesting they have a cooperative interaction. Results of plant inoculation with endophytes indicated that the growth indexes of co-inoculated MQ23+MQ23II were higher than those of inoculated alone $(\mathrm{p}<0.05)$ (the exception being for root fresh weight) when compared to negative control. There have been little of any studies of nonrhizobial putative endophytes with growthpromotion attributes in $S$. alopecuroides root nodules. This could be exploited as potential bio-inoculants and biocontrol agents in agriculture.
\end{abstract}

Key words: Plant growth promoting characterization; Sophora alopecuroides; Root nodules; Endophytic bacteria; Bacillus cereus

\section{INTRODUCTION}

In the last few decades, endophytic bacteria have attracted more and more attention as novel resources as a method of biocontrol for plant diseases and promoters of plant growth $(18,22)$. Generally, the endophytic bacteria live inside the plant tissues and do not cause visible damage or morphological change on their hosts. They can benefit the host plants by the production of IAA (indoleacetic acid, phytohormones), siderophores, and antibiotic compounds, through nitrogen fixation, by phosphate solubilization, and with the suppression of phytopathogens through competition $(16,27)$. Additionally, they may help the symbiotic rhizobia form nodules with non-specific hosts, further aiding plant growth (20). The occurrence of Bacillus species as endophytes has been reported from different plants such as pigeon pea (8), wheat, kudzu (31), and soybean nodules (26). They have been shown to benefit to their hosts by promoting nodulation and 
growth. Moreover, plant studies have shown that the beneficial effects of plant growth promoting microorganisms can be enhanced by co-inoculation with other microorganisms. Coinoculation frequently increased growth and yield compared to single inoculation $(4,8,10)$. However, up to now, nodule endophytes of $S$. alopecuroides have not yet been specifically studied.

In a recent study, we collected and characterized nodule endophytic bacteria from the legume $S$. alopecuroides (41). The aims of this experiment were (i) to identify the phylogenetic position of Bacillus cereus MQ23 and MQ23R, and (ii) to determine their promoting plant growth characterization via plant inoculation tests.

\section{MATERIALS AND METHODS}

\section{Isolation of nodule endophytes}

Healthy $S$. alopecuroides plants were collected from Northwestern China. Three nodules were randomly selected from each plant, washed with sterile distilled water to remove soil particles, and surface sterilized with $95 \%$ alcohol for $30 \mathrm{~s}$ and with $0.1 \%(\mathrm{w} / \mathrm{v}) \mathrm{HgCl}_{2}$ for $2 \mathrm{~min}$, rinsed 6-8 times to eliminate thoroughly $\mathrm{HgCl}_{2}$ with sterile distilled water. The surface sterilized nodules were crushed and streaked on yeastextract-mannitol agar (YMA) plates for the isolation of endophytic bacteria with the standard methods described previously (36). The plates were incubated at $28^{\circ} \mathrm{C}$ for 5 days and single colonies were further purified by repeatedly streaking on the same medium. In order to verify surface sterilization, aliquots of water from final rinse were spread onto the Nutrient Agar (NA) medium and incubated. Plates without any contaminants were considered effectively surface sterilized and their corresponding YMA plates were used for the isolation of endophytes. Nodulation capability was verified for nodule isolates by inoculating on surface sterilized and pregerminated seeds. The inoculated S. alopecuroides seedlings were grown for six weeks under greenhouse conditions and nodules were checked and isolated its endophtes.

\section{The nifH gene amplification}

The nifH gene encoding the $\mathrm{Fe}$ protein subunit of nitrogenase was used a molecular markers to estimate the symbiotic gene diversity and phylogeny (7). The forward primer nifH40F (5'-GGNATCGGCAAGTCSACSAC-3'), reverse primer nifH817R (5'-TCRAMCAGCATGTCCTCSA GCTC-3') and procedure described by Vinuesa et al. (37) were used for the nifH gene specific PCR assay. The PCR products were separated by horizontal electrophoresis in $1 \%(\mathrm{w} / \mathrm{v})$ agarose gels and the patterns were visualized as described (38).

\section{SDS-PAGE of whole cell protein}

Solubilized proteins were subjected to SDS-PAGE in gel slabs of $1 \mathrm{~mm}$ thickness (4\% acrylamide stacking and $12.5 \%$ acrylamide resolving gels) as described by Laemmli (17). Electrophoresis was performed in a Mini Protean II apparatus (Bio-Rad) with a discontinuous buffer system. The gel was run at $30 \mathrm{~mA}$ until the bromophenol blue marker had reached the bottom of the gel. Gels were then stained with Coomassie Brillant Blue R-250 $0.125 \%(\mathrm{w} / \mathrm{v})$ in methanol/acetic acid/water (5:1:4 v/v) and de-stained in the same solvent mixture before being swollen to their original sizes in acetic acid $7 \%(\mathrm{v} / \mathrm{v})$. Molecular weight marker polypeptides (prestained SDS-PAGE Standards-Low Range, Bio-Rad) were run in the same gels to allow the estimation of molecular weights. Visual comparisons of band patterns were made on the wet gels with transillumination.

\section{PCR-RFLP based on 16S rRNA gene}

The total genomic DNA was extracted from each of the nodule isolates outlined previously (24). In the present study, the $16 \mathrm{~S}$ rRNA gene was selectively amplified from the genomic DNA with the universal forward primer P1 (5'CGGGATCCAGAGTTTGATCCTGGCTCAGAACGAACGC T-3') and reverse primer P6 (5'-CgggATCCTACggCTACCTT 
gTTACgACTTCACCCC-3') (34) as described (33). An aliquot of PCR product was digested separately with restriction endonucleases HhaI, HaeIII, MspI, HinfI according to the producer's guide. The restricted bands were separated by horizontal electrophoresis in $2 \%(\mathrm{w} / \mathrm{v})$ agarose gels and the patterns were visualized as described previously (38).

\section{Sequencing and phylogenetic analysis}

Aliquots of PCR products of isolate MQ23 and MQ23R were directly sequenced using the same primers for PCR-RFLP analyses as described by van Berkum et al. (34). The acquired and related sequences were matched with ClustalX1.81 software, imported into Bioedit 4.8.4 and manually corrected. Phylogenetic tree were constructed using the Jukes-Cantor model and neighbor-joining (NJ) method (28) in TREECON package, and computation of the similarity of each strain tested was done with the DNAMAN application (version 6.0.3.40, lynnon corporation). The $16 \mathrm{~S}$ rRNA gene sequences obtained were submitted to NCBI GenBank (http://www.nvbi.nlm.nih. gov/) under the accession numbers HM241939, HM241940, and HM241941.

\section{Plant growth promoting characteristics of isolates}

\section{Siderophore examination}

Bacterial cultures were multiplied in Lysogeny broth (LB, $10 \mathrm{~g} \mathrm{NaCl} / \mathrm{L}$ ) for $48 \mathrm{~h}$ and aliquots of pure bacterial culture were inoculated in plates containing agar Chrome Azurol S (CAS) and incubated at $30{ }^{\circ} \mathrm{C}$. Each plate was observed daily for 7 days to detect the appearance of orange color around the colony (30). Experiments were performed in triplicate.

\section{Phosphate solubilization}

Log phase LB pure bacterial cultures were spot inoculated on Pikovasky's inorganic and Mongina organic culture plates, incubated at $30{ }^{\circ} \mathrm{C}$, and observed daily for 7 days for appearance of transparent halos (14). Experiments were performed in triplicate.

\section{Antifungal activity}

Spores of fungal cultures (Fusarium oxysporum, Magnaporthe grisea, Botrytis cinere Pers., Valsa mali Miyabe et Yamada, Alternaria alternate) were grown on Potato Dextrose Agar (PDA) plates and a small block of agar with fungal growth was cut using sterile puncher ( $\varnothing=4 \mathrm{~mm}$ ) and placed in the centre of a fresh PDA plate. Tested strains were spot inoculated on the PDA plate's edge about $25 \mathrm{~mm}$ from the centre, incubated at $30{ }^{\circ} \mathrm{C}$ for 7 days, and observed for zones of clearance. Fungal mycelia cultivated for 7 days without spot inoculation were used as control.

\section{Organic acid production}

Bacterial cultures were spot inoculated in MM9 (29) agar medium and observed for a drop in $\mathrm{pH}$ using methyl red as an indicator dye, which changes from yellow to pink below $\mathrm{pH}$ 5.0. Isolates having the ability to produce organic acid displayed a pink zone around the colony.

\section{IAA production}

Indole acetic acid (IAA) production was estimated by inoculating a bacterial suspension $\left(3 \times 10^{7} \mathrm{cfu} \mathrm{ml}^{-1}\right)$ in $10 \mathrm{ml}$ (LB) broth containing L-tryptophan $\left(100 \mu \mathrm{g} \mathrm{ml}^{-1}\right)$, and shaken in an incubator for $72 \mathrm{~h}$. IAA concentration in the culture supernatant was estimated using Sackowski’s reagent (9).

\section{Plant inoculation experiment under greenhouse conditions}

S. alopecuroides seeds were treated with $98 \%$ sulphuric acid for $60 \mathrm{~min}$, rinsed with sterile water to remove residual sulphuric acid, surface sterilized with absolute alcohol for 1 min and $0.1 \%(\mathrm{w} / \mathrm{v}) \mathrm{HgCl}_{2}$ for $2 \mathrm{~min}$, finally rinsed 6 times with sterile distilled water. Surfaced sterile seeds were then allowed to germinate axenically in Petri dishes filled with moist filter paper at $28{ }^{\circ} \mathrm{C}$, inoculated by immersing in the liquid bacterial culture with a thick suspension (approx.10 ${ }^{9}$ $10^{10} \mathrm{cfu} \mathrm{m} \mathrm{m}^{-1}$ ) for $3 \mathrm{~h}$, and grown in pots filled with sterilized vermiculate moistened with nitrogen-free plant nutrient 
solution as described by Vincent et al (36). Each isolate cultured in $5 \mathrm{ml}$ of YM broth to the exponential phase was used as inoculant. The inoculated seedlings were cultured under greenhouse conditions and programmed for a $14 \mathrm{~h} / \mathrm{d}$ photoperiod at a constant temperature of $28{ }^{\circ} \mathrm{C}$ during the day and $20{ }^{\circ} \mathrm{C}$ during the night with about $50 \%$ relative humidity. Mesorhizobium sp. MQ23II was acquired from our laboratory, and 16S rRNA sequence confirmed it as Mesorhizobium sp. All pots experiments were performed in ten repetitions with five seedlings per pot; variables used were seedlings with Mesorhizobium sp. MQ23II alone as positive control (PC), seedlings without any bacteria alone as negative control (NC), seedlings with isolate MQ23, and seedlings co-inoculated with Mesorhizobium sp. MQ23II and isolate MQ23 (1:1 v/v). The plants were harvested after six weeks when well developed nodules could be detected. Parameters such as plant biomass and dry weight, shoot and root length, and nodule number per plant were estimated compared with control plants that were not inoculated.

\section{RESULTS}

\section{Isolation and determination of endophytes}

Twenty-eight endophytes were isolated from $S$. alopecuroides root nodules. Physiological and biochemical tests were conducted (data not shown), including temperature, $\mathrm{pH}$ values and salt tolerance, antibiotic sensitivity, metal susceptibility, and dye resistance. On the basis of these characteristics, a selected strain was termed MQ23, and strain reisolated from $S$. alopecuroides nodule in plant inoculation test was termed MQ23R.

\section{The nifH gene amplification}

The results of nifH gene PCR amplification showed that isolates MQ23 and MQ23R both could produce single product bands on agarose gel by electrophoresis at the expected nifH gene fragment size, about 785bp (Figure 1), with nifH PCR primers nifH40F and nifH817R. This indicated these two isolates share common nifH gene. Since nifH encodes the highly conserved Fe protein of nitrogenase and has been used as a marker gene for nitrogenase, the presence of same nifH gene fragments in MQ23 and MQ23R strains under different environment in this study provided genetic evidence of nitrogen fixation capabilities, and a way to analyze the nitrogen fixation potential. But, nif-DNA only shows the strains that contain nitrogenase genes and does not indicate whether or not these nitrogenase genes are expressed and these strains are active and fix nitrogen. Therefore, the fact may play a significant role in nitrogen fixation under field and greenhouse environment. Further work will be necessary to address this question.

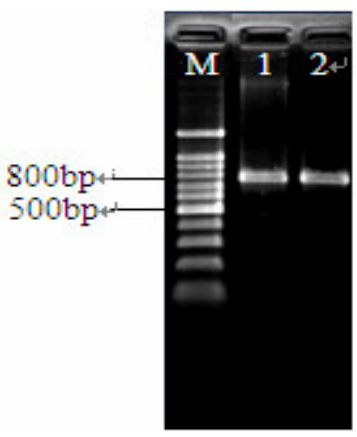

Figure 1. The nifH gene amplification of inoculated and reisolated strains (M: 100bp marker; 1:MQ23; 2:MQ23R)

\section{Identification and phylogenetic analysis of endophytes MQ23 and MQ23R}

There were some differences between MQ23 and MQ23R in its host growth environment. For example, strain MQ23 was isolated from healthy $S$. alopecuroides plants growing in Northwestern China. Where there have a dry climate, an alkaline soil profile, host $S$. alopecuroides shows the excellent performance of drought and alkaline tolerance and antisandstorm for its developed root system under field environment. However, strain MQ23R was isolated from nodules of healthy $S$. alopecuroides inoculated with MQ23 
under greenhouse conditions. Though its host growth environment existed differences, our experiment results of SDS-PAGE (Figure 2) showed that whole-cell protein profiles generated by endophytes MQ23 and MQ23R were very similar or identical, indicated exist close phylogenetic relationship between them, perhaps they have same origins. However, compared with profiles of strain MQ23II, there were many differences among them, whether the number or density of bandings. On the other side, the analysis of PCR-RFLP based on 16S rRNA gene (Figure 3) in present study indicated that restriction patterns of MQ23 and MQ23R are identical, while strain MQ23II show distinct banding patterns from them.

The phylogeny of 16S rRNA genes has been used as one of the main criteria for the differentiation of species, genera and higher taxa in current bacterial taxonomy. In this work, upon constructed phylogenetic relationship of 16S rRNA genes sequences (Figure 4) and rRNA sequence analysis we could see that isolates MQ23 and MQ23R had 100\% sequence homology, belonged to the same species. They were most related to Bacillus cereus $\mathrm{ATCC} 14579^{\mathrm{T}}$ and Bacillus thuringiensis $\mathrm{ATCC} 10792^{\mathrm{T}}$ (with $100 \%$ and $99.9 \%$ similarity, respectively), they formed a Bacillus sub-clade. Therefore, the nodule endophytes were designated as Bacillus cereus MQ23 and Bacillus cereus MQ23R.

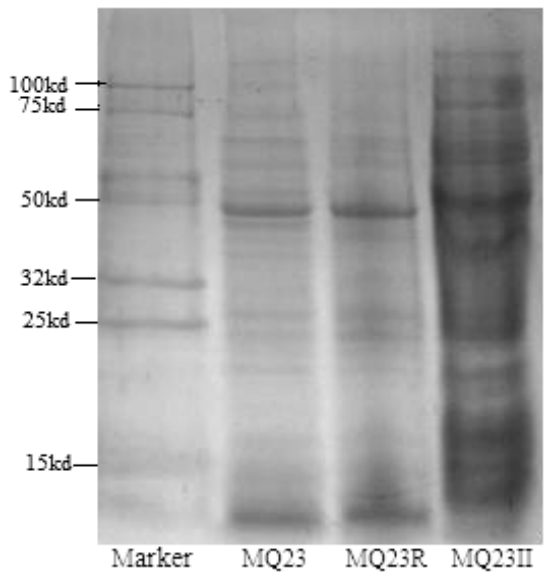

Figure 2. Protein electrophoresis pattern of SDS-PAGE. Lane's order from left to right: marker, MQ23, MQ23R, MQ23II. MQ23 was original strain, and MQ23R was reisolated from S. alopecuroides root nodule of plant reinoculation. MQ23II was a Mesorhizobium sp.

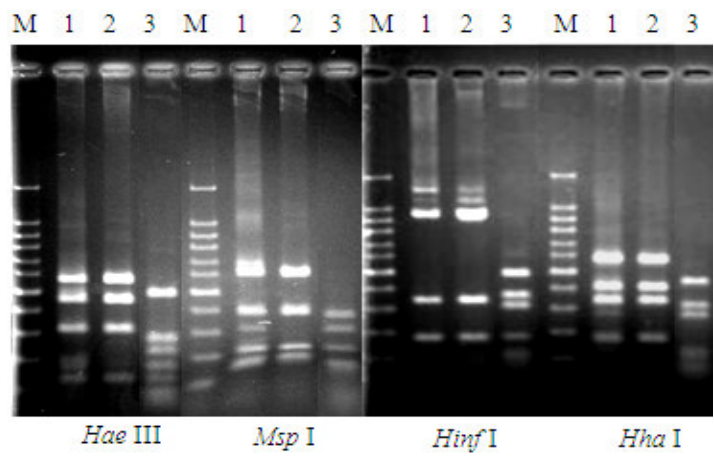

Figure 3. Electrophoretic pattern of restriction endonuclease (HaeIII, MspI, HinfI, HhaI) to strain MQ23, MQ23R and MQ23II. Lane's order from left to right: M: 100bp marker; 1: MQ23; 2: MQ23R; 3: MQ23II.

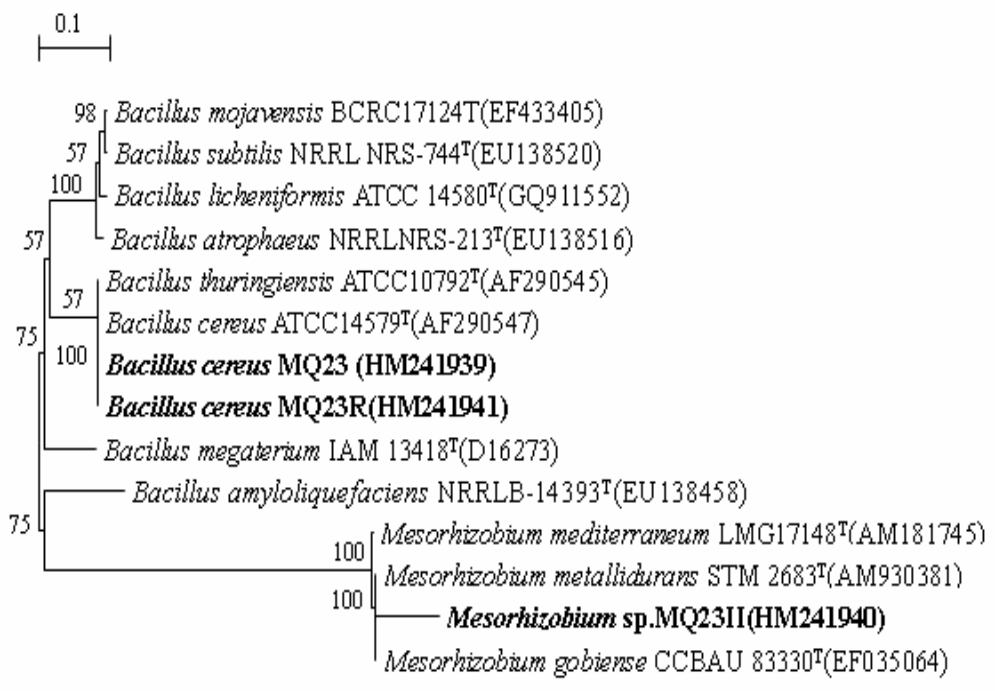

Figure 4. Neighbor joining tree based on alignment of nucleotide sequences of the 16S rRNA gene from tested strains (shown in bold) and reference strains. GenBank accession numbers were placed in parentheses. Bootstrap values greater than $50 \%$ were indicated. Scale bar represents the number of substitutions per site.

\section{Plant growth promoting characteristics of isolates}

All of three treatments MQ23, MQ23II and MQ23+MQ23II (Table1) gave a positive CAS assay showing that they all produced siderophores. Compared between of them, MQ23 showed the strongest capability of producing siderophores. As for phosphate solubilization (organic phosphate and inorganic 
phosphate), isolate MQ23 showed negative while coinoculation MQ23+ MQ23II were positive. All treatments were negative for organic acid product, positive for IAA product, and the amount of IAA produced by three treatments was $0.368 \mathrm{mg} / \mathrm{l}$, $22.385 \mathrm{mg} / \mathrm{l}$ and $23.068 \mathrm{mg} / \mathrm{l}$, respectively. Another, three treatments showed certain antifungal activity to plant pathogenic fungi, and inhibition ratios was given in Table 1. As a whole, for positive action coinoculation MQ23+MQ23II showed better effect than inoculation alone in vitro. Therefore, Bacillus cereus MQ23 and Mesorhizobium sp. MQ23II have better cooperative interaction. But definite mechanism of their interaction is further work.

Table 1. Plant growth promoting characteristics of endophytes isolated from root nodules

\begin{tabular}{|c|c|c|c|c|c|c|c|c|c|c|}
\hline \multirow{3}{*}{ Treatments } & \multicolumn{10}{|c|}{ Plant growth promoting characteristics } \\
\hline & \multirow{2}{*}{ Sid. (D/d) } & \multicolumn{2}{|c|}{ Phosphate solubilization } & \multirow{2}{*}{ - Org. acid } & \multirow{2}{*}{ IAA $(\mathbf{m g} / \mathbf{L})$} & \multicolumn{5}{|c|}{ Antifungal activity(colony diameter) } \\
\hline & & Org.P (D/d) & Inorg. P (D/d) & & & F.o $(\mathrm{cm})$ & $M . g(\mathbf{c m})$ & B. $c(\mathbf{c m})$ & $V . m(\mathbf{c m})$ & A. $a(\mathbf{c m})$ \\
\hline MQ23 & $1.65 \mathrm{aA}^{\S}$ & - & - & - & $0.368 \mathrm{aA}$ & - & - & $\begin{array}{c}+3.5 \\
\left(56.25^{*}\right)\end{array}$ & - & $\begin{array}{c}+5.5 \\
(19.12)\end{array}$ \\
\hline MQ23II & $1.11 \mathrm{bB}$ & $1.46 \mathrm{aA}$ & $1.2 \mathrm{aA}$ & - & $22.385 \mathrm{bB}$ & - & - & - & $\begin{array}{l}+4.5 \\
(40)\end{array}$ & $\begin{array}{c}+4.2 \\
(38.24)\end{array}$ \\
\hline $\begin{array}{l}\text { MQ23+ } \\
\text { MQ23II }\end{array}$ & $1.48 \mathrm{aAB}$ & $2.01 \mathrm{bB}$ & $2.0 \mathrm{bB}$ & - & $23.068 \mathrm{cC}$ & - & - & $\begin{array}{c}+3.3 \\
(58.75)\end{array}$ & $\begin{array}{l}+3.9 \\
(48)\end{array}$ & $\begin{array}{c}+4.0 \\
(41.18)\end{array}$ \\
\hline Control & I & / & / & I & - & 5.8 & 5.5 & 8.0 & 7.5 & 6.8 \\
\hline $\begin{array}{l}\text { Sid. -Siderophor } \\
\text { cinere Pers.; } V . n \\
\text { D/d means the ab } \\
\text { + positive action; } \\
\text { antifungal activit } \\
{ }^{8} \text { The same letter } \\
\text { 0.05. The data in }\end{array}$ & $\begin{array}{l}\text {; Org.P-Organ } \\
\text { - Valsa mali } M \\
\text { pility to produce } \\
\text {; - negative acti } \\
\text { y assays were } \mathrm{f} \\
\text { means no signi } \\
\text { columns is ave }\end{array}$ & $\begin{array}{l}\text { c Phosphate; Inor } \\
\text { yabe et Yamada; } \\
\text { siderophores. D-D } \\
\text { n; / blank; Control } \\
\text { ingal mycelia culti } \\
\text { ficant difference b } \\
\text { age values of five }\end{array}$ & $\begin{array}{l}\text { P-Inorganic Phospl } \\
\text { a-Alternaria altern } \\
\text { ameter of Colony anc } \\
\text { for IAA assay was L } \\
\text { ated for } 7 \text { days on PD } \\
\text { tween treatments, th } \\
\text { epetitions. }\end{array}$ & $\begin{array}{l}\text { ate; Org.acid- } \\
\text { ate. } \\
\text { halo; } \mathrm{d}-\mathrm{Colol} \\
\mathrm{B}(10 \mathrm{~g} \mathrm{NaCl} / \mathrm{L}) \\
\text { A plates witho } \\
\text { capital letter }\end{array}$ & $\begin{array}{l}\text { Organic acid; } F . o \\
\text { y diameter. } \\
\text { without inoculate } \\
\text { ut tested strains un } \\
\text { indicates significa }\end{array}$ & $\begin{array}{l}\text { Fusarium ox } \\
\text { bacterial susp } \\
\text { der the same in } \\
\text { t level at } 0.01\end{array}$ & $\begin{array}{l}\text { xysporum; } M \text {. } \\
\text { pension under } \\
\text { ncubation conc } \\
1 \text { while lowerc }\end{array}$ & $\begin{array}{l}\text {-Magnaporthe } \\
\text { ime incubation } \\
\text { tion. } \\
\text { se letter indica }\end{array}$ & $\begin{array}{l}\text { risea; } B . c-B \\
\text { ondition; Cont } \\
\text { significant } 1\end{array}$ & $\begin{array}{l}\text { trytis } \\
\text { ol for } \\
\text { vel at }\end{array}$ \\
\hline
\end{tabular}

\section{Plant inoculation assay}

To further confirm plant growth promoting characteristics, we performed plant inoculation assay. Results in Table 2 showed that each growth indexes of inoculated MQ23 except root fresh weight, slightly higher than those of negative control (NC), but only root fresh weight and root dry weight showed significant difference $(\mathrm{p}<0.05)$. Compared with MQ23II (PC), plant inoculated MQ23 only presented significant difference in nodule numbers. However, growth indexes of coinoculated MQ23+MQ23II were higher than those of inoculated alone (MQ23, PC, NC), except for root fresh weight, and showed significant difference $(\mathrm{p}<0.05)$ compare with $\mathrm{NC}$.

Table 2. Effect of Bacillus cereus MQ23 on growth and nodulation of S. alopecuroides

\begin{tabular}{|c|c|c|c|c|c|c|c|}
\hline Treatments & $\begin{array}{c}\text { Shoot length } \\
(\mathrm{cm})\end{array}$ & $\begin{array}{c}\text { Root length } \\
(\mathrm{cm})\end{array}$ & $\begin{array}{c}\text { Shoot fresh } \\
\text { weight (g/plant) }\end{array}$ & $\begin{array}{c}\text { Root fresh } \\
\text { weight (g/plant) }\end{array}$ & $\begin{array}{c}\text { Shoot dry } \\
\text { Weight (g/plant) }\end{array}$ & $\begin{array}{c}\text { Root dry weight } \\
\text { (g/plant) }\end{array}$ & $\begin{array}{c}\text { Nodule number } \\
\text { /plant }\end{array}$ \\
\hline $\begin{array}{l}\text { MQ23 } \\
\text { MQ23II }\end{array}$ & $8.6666 \pm 0.6118 \mathrm{ab} *$ & $9.9977 \pm 0.9636 \mathrm{ab}$ & $0.0797 \pm 0.0378 \mathrm{ab}$ & $0.0722 \pm 0.0119 \mathrm{~b}$ & $0.0078 \pm 0.0041 \mathrm{ab}$ & $0.0137 \pm 0.0037 \mathrm{a}$ & $\mathrm{Ob}$ \\
\hline$(\mathrm{PC})$ & $8.2317 \pm 1.4739 a b$ & $10.011 \pm 0.7859 \mathrm{ab}$ & $0.069 \pm 0.0178 \mathrm{ab}$ & $0.1159 \pm 0.0307 \mathrm{ab}$ & $0.0092 \pm 0.0025 \mathrm{ab}$ & $0.0131 \pm 0.001 \mathrm{ab}$ & $2.333 \pm 0.5774 a$ \\
\hline MQ23II+ & & & & & & & \\
\hline $\begin{array}{l}\text { MQ23 } \\
\text { Native }\end{array}$ & $9.9833 \pm 0.2021 \mathrm{a}$ & $11.9613 \pm 1.6113 a$ & $0.1276 \pm 0.0314 \mathrm{a}$ & $0.087 \pm 0.0116 \mathrm{~b}$ & $0.0123 \pm 0.0012 \mathrm{a}$ & $0.0159 \pm 0.0015 a$ & $4.333 \pm 1.5275 \mathrm{a}$ \\
\hline control (NC) & $6.38 \pm 1.0868 \mathrm{~b}$ & $9.171 \pm 0.5688 \mathrm{~b}$ & $0.0519 \pm 0.0029 \mathrm{~b}$ & $0.1542 \pm 0.0057 \mathrm{a}$ & $0.0036 \pm 0.0009 \mathrm{~b}$ & $0.0079 \pm 0.0015 b$ & $\mathrm{Ob}$ \\
\hline
\end{tabular}




\section{DISCUSSION}

\section{Endophytic Bacillus cereuses are potential $\mathbf{N}_{2}$-fixing strains}

The results of nifH gene PCR amplification (Figure 1) indicated these two isolates MQ23 and MQ23R share common nifH gene under different environment. The fact may play a significant role in nitrogen fixation under field and greenhouse environment. Ding et al. (6) reported that bacteria belonging to Bacillus sp. have been identified as plant-growth-promoting rhizobacteria, and nifH genes have been detected in some species of Bacillus cereus. Zehr et al. (40) showed that molecular tools for detection and characterization of the nitrogenase gene (nifH) can provide new information on activity of diverse nitrogen fixing organisms (12). Another, the coexistence of endophytic Bacillus cereus and symbiotic rhizobia in root nodules is an important ecological event because the coexisting bacteria may have more opportunities to exchange their core genomic and symbiont information, as revealed in other report (39).

\section{Identification of endophytes MQ23 and MQ23R}

Based on whole-cell protein profiles (Figure 2) generated by endophytes MQ23 and MQ23R, our experiment results further supported this viewpoint that combination of protein SDS-PAGE with computerized analysis of cellular protein profiles provide an effective relatively simple and reproducible approach to investigate of taxonomic relationships among many bacterial species $(5,15,23)$, such as Bacillus (13). Previous reports also showed protein profiles of SDS-PAGE as having a high degree of correlation with DNA PCR-RFLP analysis, rRNA sequence analysis, and DNA-DNA hybridization for several bacterial species $(3,11,25,35)$.

In this work, analysis of $16 \mathrm{~S}$ rRNA gene PCR-RFLP, gene sequencing and phylogeny further confirmed that defining a bacterial species based upon the consensus of combined results of several analyses can overcome the potential prejudicial grouping by each of the single analysis, supported previous studies (19).

\section{Co-inoculation enhanced plant growth}

Previous reports informed that the cooperative interactions between rhizobia and other plant root colonizing bacteria play a role in the improvement in nodulation and $\mathrm{N}_{2}$ fixation in legume plants (2); other such examples include when rhizobia are coinoculated with Rhizobium leguminosarum bv trifolii and either B. insolitus or B. brevis (32), and with Bacillus spp. and the soybean endosymbiont Bradyrhizobium japonicum $(1,21)$. Geetha et al. (8) reported that co-inoculation enhanced growth and nodulation of the pigeon pea with Bacillus strains and Rhizobium spp. Similarly, Selvakumar et al. (31) showed that the non-rhizobial plant growth promoting bacteria Bacillus thuringiensis KR-1 from the nodules of Kudzu promoted growth and positively influenced nutrient uptake in wheat seedlings. Therefore, this report extends similar observations to another legume-rhizobium system that of S. alopecuroides.

To the best of our knowledge, this is the first report about the presence of putative non-rhizobial endophytes having growth-promotion attributes in $S$. alopecuroides root nodules. Further studies are required to prove the endophytic nature of Bacillus cereus MQ23 and to harness their potential as bioinoculants and biocontrol agents in agriculture.

\section{ACKNOWLEDGEMENTS}

This work was supported by projects from the National Science Foundation of China (30970003, 30900215), RFDP (20050712013), PCSIRT of China, and Youth scientific research foundation of Shangqiu Normal University.

\section{REFERENCE}

1. Bai, Y.; Zhou, X.; Smith, D.L. (2003). Crop ecology, management and quality. Enhanced soybean plant growth resulting from coinoculation of Bacillus strains with Bradyrhizobium japonicum. Crop Sci., 43:17741781.

2. Barea, J.M.; Pozo, M.J.; Azco’n, R.; Azcón-Aguilar, C

(2005). 
Microbial cooperation in the rhizosphere. J. Exp. Bot., 56:1761-1778.

3. Berber, I.; Cokmus, C.; Atalan, E. (2003). Characterization of Staphylococcus species by SDS-PAGE of Whole-Cell and Extracellular Proteins. Microbiology. 72:42-47.

4. Chandra, S. N.; Puneet, S.C.; Sangeeta, M.D.; Karishma, S.; Ajit, V.; William, J. S. (2010). Tripartite interactions among Paenibacillus lentimorbus NRRL B-30488, Piriformospora indica DSM 11827, and Cicer arietinum L. World J. Microbiol. Biotechnol., 26:1393-1399.

5. Costas, M. (1992). Classification, identification and typing of bacteria by the analysis of their one-dimensional polyacrylamide gel electrophoretic protein patterns. In: Advances in Electrophoresis., V.5. Chrambach A, Dunn NJ and Radola BJ (Ed):351-408.

6. Ding, Y.; Wang, J.; Liu, Y.; Chen, S. (2005). Isolation and identification of nitrogen-fixing Bacillius from plant rhizospheres in Beijing region. J.Appl.Microbiol., 99:1271-1281.

7. Franck, P.; Lucile, J. M.; René, B. (2001). Improvement in the RFLP procedure for studying the diversity of nifH genes in communities of nitrogen fixers in soil. Res. Microbiol.,152: 95-103.

8. Geetha, R.; Falguni, S.; Anjana, J. D.; Archana, G. (2008). Enhanced growth and nodulation of pigeon pea by co-inoculation of Bacillus strains with Rhizobium spp.. Biores. Technol., 99:4544-4550.

9. Gordon, A.S.; Weber, R.P. (1951). Colorimetric estimation of indoleacetic acid. Plant Physiol., 26: 192-195.

10. Hildebrandt, U.; Ouziad, F.; Marner, F.J.; Bothe, H. (2006). The bacterium Paenibacillus validus stimulates growth of the arbuscular mycorrhizal fungus Glomus intraradices up to the formation of fertile spores. FEMS Microbiol. Lett,. 254:258-267.

11. Hook, L.A.; Odelson, D.A.; Bogardt, A.H.; Hemmingsen, B.B.; Labeda, D.P.; MacDonell, M.T. (1991), Numerical analysis of restriction fragment length polymorphisms and whole-cell protein banding patterns: a means of bacterial identification at the species and subspecies level. USFCC News lett., 21: 1-10.

12. Hou, J.; Huang, B. (2005). Overview of nitrogen fixation of marine cyanobacteria. Advance in earth science.,20: 312-319.

13. Ismet, B. (2004). Characterization of Bacillus species by numerical analysis of their SDS-PAGE protein profiles. J. Cell Mol. Biol., 3:33-37.

14. Katznelson, H.; Bose, B. (1959). Metabolic activity and phosphate dissolving capability of bacterial isolates from wheat root, rhizosphere and non-rhizosphere soil. Can.J.Microbiol., 5: 79-85.

15. Kersters, K. (1985). Numerical methods in the classification of bacteria by protein electrophoresis. In: Computer Assisted Bacterial Systematic. Goodfellow M, Jones D and Priest FG (Ed). London: Academic Pres. pp. 337-368.

16. Khan, Z.; Kim, S.G.; Jeon, Y.H.; Khan, H.U.; Son, S.H.; Kim, Y.H. (2008). A plant growth promoting rhizobacterium, Paenibacillus polymyxa strain GBR-1, suppresses root-knot nematode. Biores.
Technol., 99: 3016-3023.

17. Laemmli, U.K. (1970). Cleavage of structural proteins during the assembly of the head of bacteriophage T4. Nature., 227:680-685.

18. Lin, L.; Qiao, Y.S.; Ju, Z.Y.; Ma, C.W.; Liu, Y.H.; Zhou, Y.J.; Dong, H.S. (2009). Isolation and characterization of endophytic Bacillus subtilis Jaas ed1 antagonist of eggplant Verticillium wilt. Biosci. Biotechnol. Biochem., 73:1489-93.

19. Liu, J.; Wang E.T.; Chen, W.X. (2005). Diversit rhizobia associated with woody legumes Wisteria sinensis, Cercis racemosa and Amorpha fruticpsa grown in the temperate zone of China. Syst. Appl. Microbiol., 28:465-477.

20. Liu, J.; Wang, E.T.; Ren, D.W.; Chen, W.X. (2010). Mixture of endophytic Agrobacterium and Sinorhizobium meliloti strains could induce nonspecific nodulation on some woody legumes. Arch Microbiol., 192: 229-234.

21. Liu, Z.L.; Sinclair, J.B. (1993).Colonization of soybean roots by Bacillus megaterium B153-2-2. Soil Biol. Biochem., 25:849-855.

22. Marois, J.J.; Johnston, S.A.; Dunn, M.T.; Papavizas, G.C.(1982). Biological control of Verticillium wilt of eggplant in the field. Plant Disease.,66:1166-1168.

23. Merquior, V. L. C.; Peralta, J. M.; Facklam, R. R.; Teixeira, L. M. (1994). Analysis of electrophoretic whole-cell protein profiles as a toll for characterization of Enterococcus species. Curr. Microbiol., 28:149153.

24. Moulin, L., Béna, G.; Boivin-Masson, C.; pkowski, T. St. (2004). Phylogenetic analyses of symbiotic nodulation genes support vertical and lateral gene co-transfer within the Bradyrhizobium genus. Mol. Phylogenet. Evol., 30:720-732.

25. Niemi, R.M.; Niemela, S.I.; Bamford, D.H.; Hantula, J.; Hyvarinen, T.; Forsten, T.; Raateland, A. (1993). Presumptive fecal Streptococci in environmental samples characterized by one-dimensional sodium dodecyl sulfate-polyacrilamide gel electrophoresis. App. and Env. Microbiol., 59:2190-2196.

26. Oehrle, N.W.; Karr, D.B.; Kremer, R.J.; Emerich, D.W. 2000. Enhanced attachment of Bradyrhizobium japonicum to soybean through reduced root colonization of internally seedborne microorganisms. Can. J. Microbiol., 46:600-606.

27. Ryan, R.P., Germaine, K.; Franks, A.; Ryan, D. J.; Dowling, D.N. (2008). Bacterial endophytes: recent developments and applications. FEMS Microbiol. Lett., 278:1-9.

28. Saitou, N., Nei, M. (1987). The neighbor-joining method: a new method for reconstructing phylogenetic trees. Mol. Biol. Evol., 4: 406-425.

29. Sambrook, J.; Russell, D.W. (2001). Molecular Cloning: A Laboratory Manual, 3rd ed, v.1.Cold Spring Harbor, New York.

30. Schwyn, B.; Neilands, J.B. (1987). Universal chemical assay for the detection and determination of siderophore. Anal. Biochem., 160:47-56. 
31. Selvakumar, G.; Kundu, S.; Anand, D. G.; Yogesh, S. S.; Hari, S. G. (2008).Isolation and characterization of nonrhizobial plant growth promoting bacteria from nodules of kudzu (Pueraria thunbergiana) and their effect on wheat seeding growth. Curr. Microbiol., 56:134-139.

32. Sturz, A.V.; Christie, B.R.; Matheson, B.G.; Nowak, J. (1997). Biodiversity of endophytic bacteria which colonize red clover nodules, roots, stems and foliage and their influence on host growth. Biol. Fertil. Soil., 25:13-19.

33. Tan, Z.Y., Xu, X.D., Wang, E.T., Gao, J.L., Martínez-Romero, E., Chen, W.X. (1997). Phylogenetic and genetic relationships of Mesorhizobium tianshanense and related rhizobia. Int. J. Syst. Bacteriol., 47:874-879.

34. Van, B., Beyene, P. D.; Eardly, B. D. (1996). Phylogenetic relationships among Rhizobium species nodulating the common bean (Phaseolus vulgaris L.). Int. J.Syst. Evol. Microbiol., 46:240-244.

35. Vauterin, L.; Vantomme, R.; Pot, B.; Hoste, B.; Swings, J.; Kersters, K. (1990). Taxonomic analysis of Xhantomonas campestris pv. begonidae and $X$. campestris pv. pelargonii by means of phythopathological, phenotypic, protein electrophoretic and DNA hybridization methods. Syst. Appl. Bacteriol.13,166-167.

36. Vincent, J.M. (1970). The cultivation, isolation and maintenance of rhizobia. A Manual for the Practical Study of the Root-Nodule Bacteria. pp.1-13.
37. Vinuesa, P.; Leon-Barrios, M.; Silva, C.; Willems, A.; Jarabo-Lorenzo, A.; Perez-Galdona,R.; Werner, D; Martínez-Romero, E. (2005). Bradyrhizobium canariense sp. nov., an acid-tolerant endosymbiont that nodulates endemic genistoid legumes (Papilionoideae: Genisteae) from the Canary Islands, along with Bradyrhizobium japonicum bv. genistearum, Bradyrhizobium genospecies alpha and Bradyrhizobium genospecies beta. Int. J. Syst. Evol. Microbiol., 55:569-575.

38. Wang, E.T.; Berkum, P.; Sui, X.H.; Beyene, D.; Chen, W.X.; MartinezRomero, E. (1999). Diversity of rhizobia associated with Amorpha fruticosa isolated from Chinese soils and description of Mesorhizobium amorphae sp nov. Int. J. Syst. Bacteriol., 49:51-66.

39. Wang, L.L.;Wang, E.T.; Liu, J.; Li, Y.; Chen, W.X. (2006). Endophytic occupation of root nodules and roots of Melilotus dentatus by Agrobacterium tumefaciens. Microbial. Ecol., 52:436-443.

40. Zehr, J.P., Braun, S.; Chen, Y.; Mellon, M. (1996). Nitrogen fixation in the marine environment: relating genetic potential to nitrogenase activity. J. Exp. Mar. Biol. Ecol., 203:61-73.

41. Zhao, L.F.; Deng, Z.S,; Yang, W.Q.; Cao, Y.; Wang, E.T.; Wei, G.H. (2010). Diverse rhizobia associated with Sophora alopecuroides grown in different regions of Loess Plateau in China. Syst. Appl. Microbio. doi:10.1016/j.syapm.2010.08.004. 